\title{
REPRESENTASI CITY BRANDING JAKARTA MELALUI IDENTITAS MEREK ASIAN PARA GAMES 2018
}

\author{
Atiek Nur Hidayati ${ }^{1}$, Yulianto Hadiprawiro ${ }^{2}$, Angga Kusuma Dawami ${ }^{3}$ \\ Program Studi Desain Komunikasi Visual \\ Fakultas Bahasa dan Seni Universitas Indraprasta PGRI ${ }^{123}$
}

\begin{abstract}
Abstrak. Penelitian ini akan mengeksplorasi representasi city branding Jakarta melalui identitas merek Asian Para Games 2018. Asian Para Games sebagai sport mega event dapat menjadi akselerasi dalam membentuk city branding. Pendekatan kualitatif digunakan dengan studi kasus identitas merek Asian Para Games 2018 yang dikaitkan dengan elemen identitas city branding. Identitas merek yang akan dianalisis adalah logo, maskot dan slogan. Hasil penelitian ini adalah (1) logo, maskot, dan slogan Asian Para Games 2018, merupakan representasi dari visual difabel yang mengangkat konsep kesetaraan antara difabel dan non-difabel, sehingga tidak memberikan gambaran yang diskriminatif (2) visual difabel tidak harus selalu muncul jelas pada logo, maskot dan slogan; (3) identitas merek Asian Para Games 2018 merupakan salah satu citra city branding Jakarta yang diilustrasikan melalui elemen visual acara olahraga difabel terbesar di Asia.
\end{abstract}

Keywords: City Branding, Asian Para Games 2018, Identitas Merek, Difabel

\begin{abstract}
This research studies the representation of Jakarta city branding through brand identity of Asian Para Games 2018. Asian Para Games as the Sport mega event can become acceleration in building city branding. Qualitative approach is being applied with case study Brand identity of Asian Para Games 2018 related to identity elements of city branding. The logo, mascot and slogan are the brand identity that being analyzed in this research. The research concludes that (1) The Asian Para Games 2018 Logo, mascot and slogan represent the visual of difabel image which deliver equality among the difabel itself and non-difabel, therefore it doesn't convey any discrimination appearance, (2) the difabel image does not always obviously be seen in logo, mascot or slogan, (3) Brand identity of Asian Para Games 2018 profides the role of Jakarta city branding image that being visualized through visual elements of sport mega events specifically Asian Para Games 2018.
\end{abstract}

Keywords: City Branding, Asian Para Games 2018, Brand Identity, Difabel

Correspondence author: Atiek Nur Hidayati, atiek.nur07@gmail.com, Jakarta, Indonesia

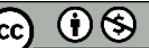

This work is licensed under a CC-BY-NC

\section{Pendahuluan}

Konsep city branding di Jakarta sebenarnya bukanlah hal baru, Jakarta melalui slogan "enjoy jakarta" diluncurkan oleh pemerintah kota Jakarta pada tahun 2006 yang fokus pada pencitraan kota untuk meningkatkan kunjungan wisatawan mancanegara dan wisatawan 
domestik (Ivana 2015). Infrastruktur kota yang bersifat hiburan dan atraksi seperti pusat perbelanjaan, sarana hiburan dan akomodasi dibangun untuk menunjang konsep city branding tersebut. City branding adalah sebuah manajemen citra suatu tempat melalui inovasi strategis serta kordinasi ekonomi, komersial, sosial, kultural, dan peraturan pemerintah yang fokus pada pengelolaan citra, tepatnya apa dan bagaimana citra itu akan dibentuk serta aspek komunikasi yang dilakukan dalam proses pengelolaan citra (Anholt) (Kavaratzis). Manfaat city branding adalah meningkatkan kepercayaan dan menunjukkan citra sebuah kota kepada masyarakat dunia sehingga mereka dapat melakukan investasi, pariwisata, dan ekspor impor ke kota tersebut.

Salah satu cara untuk menaikkan citra tempat, kota atau negara selain membentuk slogan salah satunya dengan menjadi tuan rumah sport mega-event. Artikel ini akan menunjukkan bahwa menjadi tuan rumah sport mega-event dapat membentuk identitas dan citra bangsa yang menjadi cikal bakal terbentuknya city branding. Terdapat pandangan bahwa menjadi tuan rumah sport mega-event dapat menjadi agen pencitraan, pencitraan ulang dan pencitraan kota dan Negara (Hinch and Higham). Penyelenggararan sport mega-event selalu melibatkan banyak media yang menyoroti mulai dari persiapan, pembukaan, penyelenggaraan hingga penutupan sehingga warga negara dan masyarakat dunia dapat menilai bagaimana keberhasilan tuan rumah dalam menyelenggarakan sport mega-event. Saat ini banyak kota yang berharap menjadi tuan rumah mega event olahraga untuk mencapai manfaat dalam politik, diplomasi, dan ekonomi, yang pada gilirannya akan mengangkat citra bangsa dan kotakota yang terlibat (Herstein and Berger). Menjadi tuan rumah sport mega event menjadi upaya untuk membentuk citra atau reputasi, ini diperlukan untuk membangun positioning yang tepat bagi sebuah kota kaitannya dengan produk-produk yang mereka hasilkan dalam konteks pemasaran internasional. DKI Jakarta sebagai ibukota Indonesia pada tahun 2018 mendapatkan kesempatan besar sebagai tuan rumah dua mega event olahraga yaitu Asian Games 2018 dan Asian Para Games 2018.

Penelitian ini akan fokus membahas tentang Asian Para Games 2018 sebagai sport mega event khusus difabel yang menjadi momentum untuk mempromosikan sekaligus menyampaikan kepada masyarakat bahwa difabel juga memiliki perlehatan olahraga besar layaknya Asian Games yang diselenggarakan Agustus 2018. Penyandang Disabilitas atau lebih banyak dikenalkan dengan nama Difabel dari kepanjangan Different Ability People. Dalam acara tersebut memiliki implikasi signifikan untuk memasukkan masyarakat difabel sebagai peserta, klien, penonton, karyawan, pekerja kontrak, dan sebagai sukarelawan sehingga muncul kesetaraan dan memiliki pengalaman yang sama dengan masyarakat biasa (Darcy). Indonesia berkomitmen penuh dalam konvensi PBB tentang hak penyandang disabilitas (asli: UNCRPD) yang telah diratifikasi menjadi UU No. 19 tahun 2011 untuk mengembangkan wawasan masyarakat akan persoalan disabilitas dan memberikan dukungan untuk meningkatkan martabat, hak, dan kesejahteraan para difabel, terutama atlet. Peraturan pemerintah yang mendukung gerakan Difabel jelas terlihat untuk Asian Para Games 2018.

Asian Para Games 2018 merupakan sport mega event yang melibatkan atlet difabel dari seluruh Asia. Sport mega events adalah acara olahraga yang durasinya singkat, yang secara signifikan meningkatkan fenomena di era globalisasi (Hall). Definisi mega-events adalah event yang terencana dalam periode waktu terbatas, yang memberikan efek terhadap wilayah tuan rumah, jumlah perjalanan wisata, pengeluaran wisatawan, hasil promosi event meningkatkan kesadaran dan memberikan lebih banyak citra positif, infrastruktur yang relevan, sorotan media dan pengembangan organisasi yang sangat meningkatkan potensi dan daya tarik (Getz). Mega-events ukurannya lebih besar dibanding regular events yang mengekstraksi empat 
dimensi utama dari berbagai definisi yang ada tentang mega events yaitu daya tarik pengunjung, jangkauan yang dimediasi, biaya dan dampak transformatif (Müller).

Banyak negara berkembang telah mengambil risiko besar dalam bertaruh bahwa hosting acara besar dapat menjadi jalur cepat untuk pengakuan dunia dan peningkatan reputasi, dan ada banyak bukti bahwa taruhan ini memiliki hasil dalam dampak positif pada citra dan reputasi negara sebagai produsen produk dan sebagai tujuan wisata. Manfaat yang terkait dengan acara sport mega events adalah besarnya atensi media, pengembangan identitas nasional dan kebanggan, perubahan citra dan soft power (Knott et al.).

Penelitian ini akan mengeksplorasi representasi city branding kota Jakarta melalui identitas merek Asian Para Games 2018. Menurut Aaker identitas merek memberikan arahan, tujuan, dan makna strategis untuk suatu merek yang membantu membangun hubungan antara merek dan pelanggan dengan menghasilkan proposisi nilai yang melibatkan manfaat fungsional, emosional, atau ekspresif diri (Ghodeswar). Identitas mengacu pada akar merek dan warisan segala sesuatu yang membuatnya unik memiliki otoritas dan legitimasi dalam ranah nilai dan manfaat yang tepat (Kapferer). Identitas merek salah satu bentuknya adalah nama, logo, warna, tagline, dan symbol sebuah merek (Kotler et al.). Aaker dan Joachimsthaler dalam (Ghodeswar) menyatakan identitas merek merepresentasikan bagaimana sebuah organisasi ingin menunjukkan merek mereka kepada konsumen. Identitas merek merupakan asosiasi merek yang unik yang menunjukkan janji kepada konsumen. Agar menjadi efektif, identitas merek perlu beresonansi dengan konsumen, membedakan merek dari pesaing, dan mewakili apa yang dapat dan akan dilakukan oleh sebuah organisasi dari waktu ke waktu.

Logo adalah tampilan grafis dari nama merek perusahaan, event atau organisasi yang memiliki kekuatan symbol tidak boleh dianggap remeh karena manusia cenderung menjadi lebih mudah menerima citra dan simbol dibanding yang lainnya sehingga menciptakan kesadaran merek (Kotler\& Pfoerstch,2008) dalam (Aji). Konsep visual logo dan kemasan yang kuat akan memberikan dampak penjualan yang kuat pula (Dawami, 2019). Maskot adalah orang, hewan, atau bentuk lain yang merepresentasikan sifat manusia dan dianggap dapat membawa keberuntungan dan merepresentasikan identitas organisasi, produk, event olahraga (Kurniawan and Sayatman). Selain itu menurut Kent Wertime (2003) maskot memiliki nilai komersial yang tinggi karena memicu ingatan dan membentuk koneksi dengan elemen-elemen yang lebih fundamental dari otak (Lauwrentius et al.). Slogan memiliki peran yang unik dalam penciptaan identitas merek yang harmonis. Slogan adalah kalimat yang mudah dikenal dan diingat yang seringkali menyertai nama merek dalam komunikasi pemasaran. Tujuan utama slogan adalah mendukung citra merek yang diproyeksikan oleh nama dan logo merek (Kotler\&Pfoertsch, 2008) (Aji).

\section{Metode Penelitian}

Penelitian ini menggunakan pendekatan kualitatif dengan studi kasus Asian Para Games 2018. Metodologi studi kasus adalah pemeriksaan hal-hal yang berhubungan dengan penyelidikan berbasis kasus. Penelitian studi kasus biasanya membutuhkan penggambaran metode melalui tinjauan pustaka dan wawancara mendalam untuk memahami pengalaman, perspektif, dan pandangan dunia orang-orang dalam keadaan tertentu (Denzin and Lincoln).

Fokus analisisnya adalah mengkaitkan identitas merek Asian Para Games 2018 dengan elemen identitas city branding. Menurut Noordman dalam (Govers and Go) Elemen yang mendefinisikan identitas city branding, yaitu elemen struktural (lokasi dan sejarah); elemen 
semi-statis (ukuran, penampilan fisik dan mentalitas batin); dan elemen warna (simbolisme, perilaku, dan komunikasi). Identitas merek yang akan dianalisis adalah logo, maskot dan slogan.

\section{Hasil dan Pembahasan}

Pada pertengahan Oktober 2018, Indonesia menjadi tuan rumah ajang pesta olahraga Asian Para Games 2018. Asian Para Games 2018 diselenggarakan pada 6-13 Oktober 2018 di Jakarta setelah berakhirnya multi event Asian Games 2018. Asian Para Games adalah pesta olahraga negara-negara Asia yang pesertanya merupakan atlet difabel. Ajang ini disepakati menjadi sport multi events empat tahunan yang satu paket dengan penyelenggaraan dengan Asian Games di suatu negara atau kota. Asian Para Games 2018 di Jakarta merupakan perhelatan ketiga setelah sebelumnya berlangsung di Guangzhou, China 2010 dan Incheon, Korea Selatan 2014. Event Asian Para Games 2018 diikuti oleh 41 negara dengan 18 cabang olahraga khusus difabel yang dipertandingkan yang diikuti 2.888 atlet. Sport mega-event bagi para kaum difabel di Asia itu juga melibatkan 8.000 relawan, 5.000 pekerja lapangan, 1.826 offisial, dan diliput 800 media dari dalam dan luar negeri. Inapgoc sebagai panitia pelaksana juga menyediakan 17 arena pertandingan di Jakarta diantaranya Kawasan Gelora Bung Karno (GBK), Gelanggang Remaja Tanjung Priok, Cempaka Putih Sport Hall, Sentul International Circuit, Jakarta International Velodrome, Balai Kartini, Ji Expo Kemayoran, Balai Sudirman, Jaya Ancol Bowling Centre, POPKI Cibubur dan Klub Kelapa Gading.

Dalam event ini Inapgoc (Indonesia Asian Para Games 2018 Organizing Commitee) sebagai penyelenggara memperkenalkan logo, slogan dan maskot Asian Para Games 2018. Ajang ini mengusung konsep kesetaraan, keadilan dan keberagaman tanpa memandang kekurangan fisik manusia. Logo, maskot dan slogan selanjutnya diaplikasikan ke seluruh media promosi, baik secara cetak, elektronik dan digital. Tujuannya untuk mensosialisasikan Asian Para Games 2018 ke masyarakat lokal, wisatawan asing dan investor.

\section{Konsep Logo}

Konsep logo Asian Para Games 2018 adalah harmoni yang merupakan bentuk keselarasan dan keseimbangan dalam alam sekitar dan lingkungan dalam menjalani kehidupan sehari-hari. Hal tersebut dituangkan dalam elemen-elemen logo yaitu kumpulan potongan simetris membentuk lingkaran dan di tengahnya terdapat siluet manusia. Kumpulan potongan simetris berbentuk lingkaran mewakili siluet Stadion Utama Gelora Bung Karno (SUBK) dari atas. Sementara itu siluet tubuh manusia yang bergerak di pusat lingkaran menggambarkan pergerakan atlet untuk meraih kemenangan sekaligus merepresentasikan "Energy of Asia". Terdapat tiga kurva dalam tiga warna disekeliling siluet pria yang melambangkan keseimbangan yang terbentuk dari keberagaman bangsa-bangsa di Asia yang bergerak bersama dalam kesatuan untuk kemajuan bersama. Dalam logo tersebut terdapat tiga warna yang melambangakan elemen dasar dalam filsafat hidup bangsa-bangsa di Asia yaitu biru untuk langit, oranye untuk matahari dan hijau untuk alam. Sedangkan warna ungu dan pink masing-masing melambangkan kedekatan dan semangat. Konstruksi visual logonya memberikan warna baru dan merupakan representasi dari semangat tentang kesetaraan difabel. 


\section{裙 \\ INDONESIA \\ 2018 \\ ASIAN PARA GAMES}

Gbr. 1 Logo Asian Para Games 2018 (sumber: asianparagames.tempo.co diakses pada 15 April 2019)

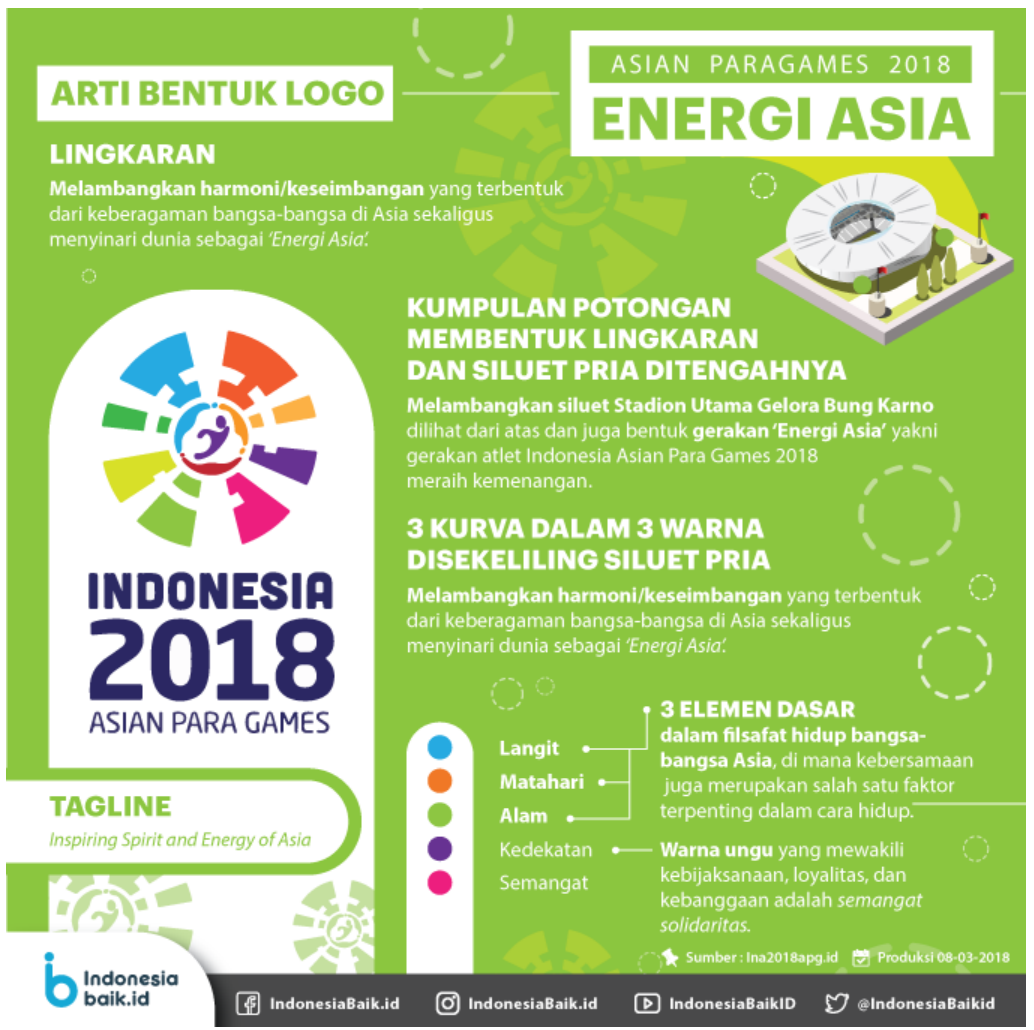

Gbr. 2 Arti Logo Asian Para Games 2018

(sumber: asianparagames.tempo.co diakses pada 15 April 2019)

Logo APG 2018 mengandung elemen identitas city branding, yaitu elemen struktural yang ditunjukkan dengan adanya gambaran landmark Stadion Utama Gelora Bung Karno (SUBK) sebagai stadion kebanggan Jakarta karena merupakan stadio pertama yang ada di Indonesia. Selanjutnya elemen semi statis yang dilambangkan dengan adanya siluet manusia yang sedang bergerak. Terakhir elemen warna yang mengusung warna-warna simbol filsafat hidup masyarakat di Asia. Visual difabel hanya terpampang di tengah, namun tetap tidak mencerminkan difabel yang lemah, bahkan menjadi identitas utama dalam Asian Para Games 2018. 


\section{Konsep Maskot}

Maskot Asian Para Games 2018 adalah "Momo" yang merupakan singkatan dari mobilitas dan motivasi. Momo merepresentasikan simbol kota Jakarta. Momo mengenakan sarung dan sabuk khas tradisional Betawi, yang artinya seeseorang harus tetap melangkah ke depan dan harus mampu beradaptasi dengan mudah terhadap perubahan dunia. Lalu Inspirasi Elang Bondol dibuat karena Elang Bondol hanya hidup di Pulau Seribu dan merupakan satwa yang dilindungi karena sudah langka. Tema besar yang diangkat dalam penggambaran karakter maskot Momo juga terlihat dari pemakaian unsur khas tradisi lokal Jakarta berupa stilasi pakaian adat khas Betawi, berupa sarung yang dikalungkan pada leher, dan sabuk hijau.

Elemen identitas city branding yang terdapat dalam maskot Asian Para Games adalah elemen struktural yang menunjukkan elang bondol sebagai ikon kota Jakarta yang menggunakan atribut khas betawi yaitu sarung dan sabuk hijau. Elemen semi statis digambarkan dengan karakter elang bondol yang mencerminkan kekuatan. Elemen warna apat dilihat dari penggunaan atribut betawi berupa sarung dan sabuk berwarna hijau yang artinya seeseorang harus tetap melangkah ke depan dan harus mampu beradaptasi dengan mudah terhadap perubahan dunia.

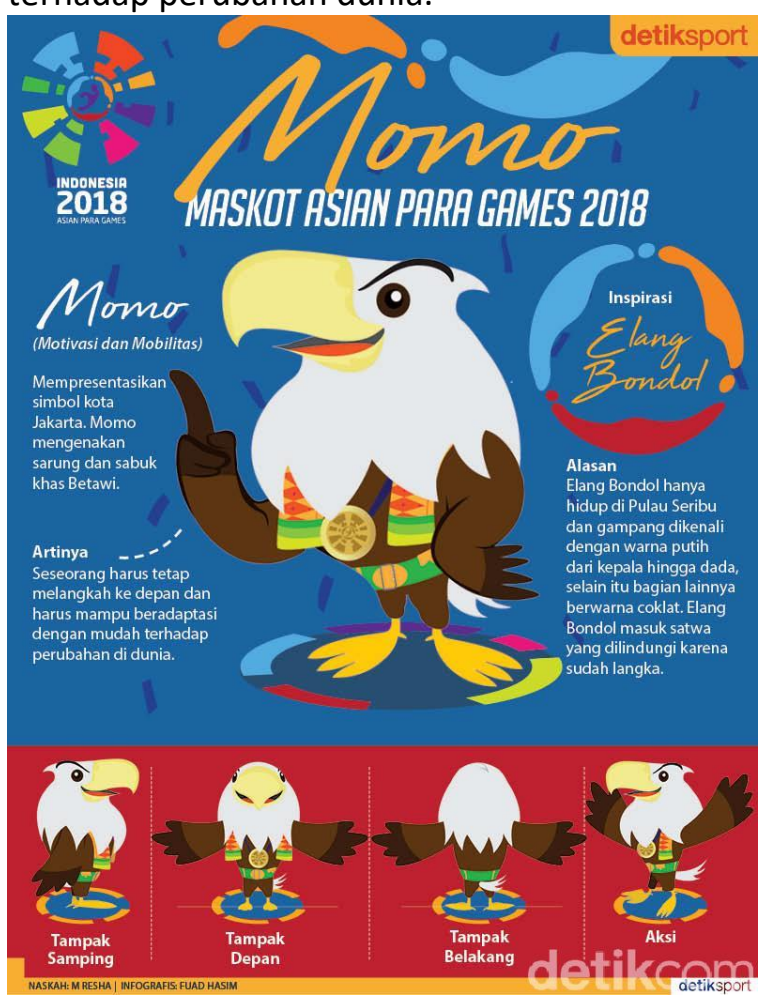

Gbr. 3 Maskot Asian Para Games 2018

(sumber: detik.com diakses pada 11 April 2019)

\section{Konsep Slogan}

Slogan Asian Para Games 2018 yakni "Inspiring Spirit and Energy of Asia" yang memiliki arti semangat yang menggelora dengan sebuah pergerakan memberikan energi positif kepada semua sehingga menjadi inspirasi bagi umat manusia. Elemen identitas city branding yang tergambarkan melalui slogan adalah elemen struktural fokus pada penggunanaan kata Asia yang menrepresentasikan kompetisi atlet difabel di kawasan Asia; Elemen semi-statis tertuang dalam kalimat The Inspiring Spirit yang memotivasi masyarakat bahwa semangat atlet difabel dapat dijadikan inspirasi untuk menjalani hidup; dan elemen warna tertuang pada kalimat 
Energy of Asia yang menunjukkan bahwa negara-negara Asia siap berkompetisi dan bersinergi dengan bangsa-bangsa lain.

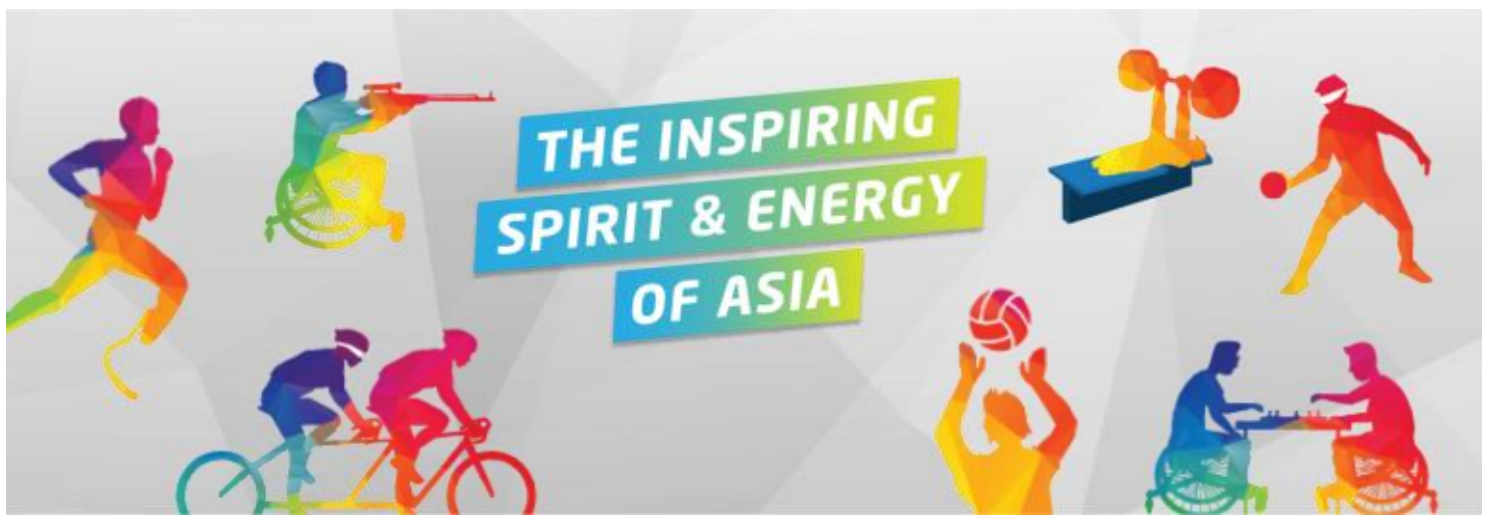

Gbr. 4 Slogan Asian Para Games 2018

(sumber: detik.com diakses pada 15 April 2019)

\section{City branding melalui Event Olahraga Difabel}

Visual difabel dimunculkan dalam identitas yang berbeda. Membentuk paradigma baru terhadap difabel melalui event olahraga. Identitas merek secara simbolis dituangkan melalui logo, slogan tema, maskot dan sejenisnya, dan secara material melalui konstruksi bangunan dan infrastruktur. Representasi city branding tidak hanya tercermin pada identitas merek Asian Para Games 2018 secara simbolis melalui logo, maskot dan slogan. Infrastruktur, media promosi dan pelayanan sebelum dan selama even berlangsung juga penting. Demi kesuksesan Asian Para Games 2018, pemerintah kota Jakarta bekerjasama dengan Inapgoc (panitia penyelenggara Asian Para Games 2018) mempersiapkan semua fasilitas, media promosi dan pelayanan bagi seluruh masyarakat dan atlet yang terlibat didalam event tersebut. Yang pertama adalah infrastruktur dan akomodasi, dimulai dengan merenovasi Stadion Utama Gelora Bung Karno (SUBK) serta membuat wisma atlet dan menyediakan transportasi ramah difabel. Kedua adalah media promosi event Asian Para Games menggabungkan kekuatan media cetak, media elektronik dan media digital. Selain itu diadakan pula pawai obor Asian Para Games 2018 di beberapa kota di Indonesia. Ketiga adalah pelayanan yang diberikan kepada para atlet dan official, masyarakat lokal dan asing serta media baik lokal ataupun asing. Pelayanan ini direpresentasikan melalui hiburan dan fasilitas memadai bagi atlet dan official. Kemudahan untuk menyaksikan semua kompetisi bagi masyarakat serta adanya media room dengan fasilitas yang sesuai standar bagi media.

\section{Simpulan}

Asian Para Games 2018 di Indonesia membentuk paradigma baru bahwa difabel tidak hanya sekedar objek namun juga didukung untuk menjadi salah satu usaha untuk mengenalkan difabel dan konsep kesetaraan diberbagai sektor. Bentuk aplikasi (1) konsep logo, maskot, dan slogan, merupakan representasi dari visual difabel yang ada di masyarakat. Konsep kesetaraan antara difabel dan non-difabel, muncul dengan tidak memberikan gambar yang diskriminatif. Terlihat bagaimana logo dan maskot, tidak mencerminkan visual difabel secara kasar, bergambar kursi roda atau alat bantu difabel lain. Sehingga (2) Tidak selalu visual difabel muncul pada logo, maskot dan slogan. Acara (3) Asian Para Games 2018 merupakan 
salah satu usaha dalam city branding kota Jakarta. Kota Jakarta sebagai ibukota negara Indonesia telah berhasil menyelenggarakan Asian Para Games 2018, hal tersebut membuat citra kota sebagai kota ramah difabel patut disematkan. Yang penting dalam penyelenggaraan sport mega events selanjutnya masyarakat difabel dan non-difabel dapat lebih mempersiapkan diri dan bekerjasama untuk mengetahui secara konsisten apa yang akan mereka katakan dan buktikan sama pada saat Asian Para Games 2018.

Penelitian tentang acara difabel di Indonesia perlu dikembangkan. Wacana tentang kesetaraan difabel dan non-difabel sudah dimulai sejak adanya UU no. 6 tahun 2018, bahkan sebelum itu. Adanya Asian Para Games 2018, menjadi salah satu titik tolak untuk membentuk konstruksi stigma difabel lebih baik. Acara-acara difabel di berbagai sektor menjadi isu yang menarik untuk dapat dilihat secara detail. Mencari wacana-wancana kesetaraan, pengubahan stigma tentang difabel, dan advokasi yang dilakukan oleh difabel merupakan konstruksi yang menarik untuk diteliti lebih lanjut.

\section{Ucapan Terima Kasih}

Apresiasi dan terima kasih kepada Lembaga Penelitian dan Pengabdian Masyarakat Universitas Indraprasta PGRI yang telah membantu sebagian biaya kegiatan Penelitian tahun 2019 dengan judul: "Komunikasi Visual Acara Khusus Disabilitas di Indonesia" melalui Kontrak Penelitian: Nomor: 0382/SP3/KP/LPPM/UNINDRA/III/2019, Tanggal 25 Maret 2019.

\section{Daftar Pustaka}

Aji, Fernadi Hutomo. "Analisa Pengaruh Brand Identity Terhadap Brand Awareness Dan Brand Satisfaction Brotherwood Decoration Surabaya." Jurnal Strategi Pemasaran, vol. 3, no. 1, 2015, pp. 1-10.

Anholt, Simon. Places: Identity, Image and Reputation. Palgrave Macmillan, 2010.

Darcy, Simon. "Disability, Access, and Inclusion in the Event Industry: A Call for Inclusive Event Research." Event Management, vol. 16, no. 3, 2012, pp. 259-65.

Denzin, Norman K., and Yvonna S. Lincoln. The Sage Handbook of Qualitative Research. Sage, 2011.

Getz, Donald. "Event Tourism: Definition, Evolution, and Research." Tourism Management, vol. 29, no. 3, June 2008, pp. 403-28. Crossref, doi:10.1016/j.tourman.2007.07.017.

Ghodeswar, Bhimrao M. "Building Brand Identity in Competitive Markets: A Conceptual Model." Journal of Product \& Brand Management, vol. 17, no. 1, 2008, pp. 4-12.

Govers, Robert, and Frank M. Go. Place Branding: Glocal, Virtual and Physical Identities, Constructed, Imagined and Experienced. Palgrave Macmillan, 2009.

Hall, C. Michael. "Urban Entrepreneurship, Corporate Interests and Sports Mega-Events: The Thin Policies of Competitiveness within the Hard Outcomes of Neoliberalism." The Sociological Review, vol. 54, no. 2_suppl, Dec. 2006, pp. 59-70. Crossref, doi:10.1111/j.1467-954X.2006.00653.x. 
Herstein, Ram, and Ron Berger. "Much More than Sports: Sports Events as Stimuli for City Re-branding." Journal of Business Strategy, vol. 34, no. 2, Mar. 2013, pp. 38-44. Crossref, doi:10.1108/02756661311310440.

Hinch, T. D., and J. E. S. Higham. "Sport Tourism: A Framework for Research." International Journal of Tourism Research, vol. 3, no. 1, Jan. 2001, pp. 45-58. Crossref, doi:10.1002/1522-1970(200101/02)3:1<45::AID-JTR243>3.0.CO;2-A.

Kapferer, Jean-Noël. The New Strategic Brand Management: Creating and Sustaining Brand Equity Long Term. 4th ed., New ed, Kogan Page, 2008.

Kavaratzis, Mihalis. "Cities and Their Brands: Lessons from Corporate Branding." Place Branding and Public Diplomacy, vol. 5, no. 1, Feb. 2009, pp. 26-37. Crossref, doi:10.1057/pb.2008.3.

Knott, Brendon, et al. "Sport Mega-Events and Nation Branding: Unique Characteristics of the 2010 FIFA World Cup, South Africa." International Journal of Contemporary Hospitality Management, vol. 29, no. 3, Mar. 2017, pp. 900-23. Crossref, doi:10.1108/IJCHM-092015-0523.

Kotler, Philip, et al. B2B Brand Management. Springer, 2006.

Kurniawan, Ferdian Lutfi, and Sayatman Sayatman. "Perancangan Maskot Untuk Memperkuat Identitas Visual Kota Kediri." Jurnal Sains Dan Seni ITS, vol. 7, no. 1, 2018, pp. 48-52.

Lauwrentius, Stephen, et al. "PENCIPTAAN CITY BRANDING MELALUI MASKOT SEBAGAI UPAYA MEMPROMOSIKAN KABUPATEN LUMAJANG." Jurnal Art Nouveau, vol. 4, no. 2, 2015, pp. 162-71.

Müller, Martin. "What Makes an Event a Mega-Event? Definitions and Sizes." Leisure Studies, vol. 34, no. 6, Nov. 2015, pp. 627-42. Crossref, doi:10.1080/02614367.2014.993333. 